\title{
PEMANFAATAN WADAH BERBAGI PENGETAHUAN DAN KUALITAS MEREK TERHADAP PERILAKU LOYALITAS KONSUMEN
}

\author{
Sam Oudom Serick \\ PT Rka Artha Nusantara \\ redkank.rpi@gmail.com \\ Bambang Purwoko \\ Universitas Pancasila \\ bambang.purwoko@univpancasila.ac.id \\ Derriawan \\ Universitas Pancasila \\ derriawan@univpancasila.ac.id \\ Lingga Yuliana \\ Universitas Paramadina \\ lingga.yuliana@lecturer.paramadina.ac.id
}

\begin{abstract}
In this study, a brand of herbal medicine called Red Kank (cancer suppression) was initially described strongly as a cancer reducer but has now evolved into cancer-fighting products, such as health and beauty products. This strategic step has not been able to answer whether it leads to its success. Still, it opens the possibility to assess the quality of brand relationships, use of knowledge sharing platforms and their impact on consumer loyalty behavior Red Kank. Primary data were collected using a purposive sampling technique from Jakarta, Bekasi, Surabaya, and Balikpapan customers. The data analysis use Structural Equation Modeling (SEM) by Lisrel 8.7. Statistical results show that the quality of the brand relationship is closely related to the image of the quality of the product itself. Therefore, the company's strategy to diversify begins with increasing understanding of product brands to become company brands.
\end{abstract}

Keywords: brand relationship quality; customer loyalty behavior; knowledge sharing platform.

\section{PENDAHULUAN}

Perkembangan dunia usaha saat ini semakin kompleks. Hal ini ditandai dengan persaingan yang semakin ketat dan kondisi pasar yang sangat dinamis serta kompetitif. Kondisi ini menyebabkan pelanggan juga semakin cerdas. Pelanggan memiliki akses ke banyak saluran dan pilihan terhadap produk yang mereka butuhkan. Pelanggan dapat dengan mudah beralih ke pesaing yang menjanjikan penawaran yang lebih baik dengan harga yang lebih rendah (Merdiani, 2021). Kondisi ini membuat perusahaan harus semakin akurat dalam menentukan strategi bisnis yang efektif dan efisien dalam menghadapi kompetisi yang ada. Perusahaan dapat melakukan strategi berupa penetrasi pasar, pengembangan produk, pengembangan pasar hingga diversifikasi dalam mengembangkan bisnis (Pramestika et al., 2020).

Pelanggan sebagai salah satu pemangku kepentingan memiliki peran yang penting bagi keberlangsungan perusahaan. Dalam lingkungan yang terus berkembang dan berubah dengan cepat, kunci keberhasilan perusahaan agar dapat bertahan hidup adalah memertahankan hubungan jangka panjang dengan para pemangku kepentingan (Sridadi, 2013). Tantangan yang dihadapi semua pemasar adalah meningkatkan loyalitas pelanggan. Mengubah pelanggan yang acuh tak acuh menjadi pelanggan yang setia dan membangun hubungan jangka panjang sangat penting bagi keberhasilan perusahaan (Kaur \& Bhardwaj, 2021).

PT. Mahatherapoeitika sebagai salah satu produsen produk obat herbal di Indonesia dengan merek Red Kank. Red Kank sebagai obat alternatif yang dikenal sebagai "Redam Kanker" merupakan produk unggulan PT. Mahatherapoeitika yang bisa mencetakan penjualan miliaran rupiah setiap bulannya. 
Serick et al. Pemanfaatan Wadah Berbagi Pengetahuan dan Kualitas Merek terhadap Perilaku Loyalitas Konsumen

Penjualan produk Red Kank tahun 2013-2015 dideskripsikan pada gambar 1. Pada gambar tersebut menunjukkan bahwa penjualan produk Red Kank mengalami peningkatan yang sangat signifikan dari tahun 2013 ke tahun 2014 (Tjetje, 2016).

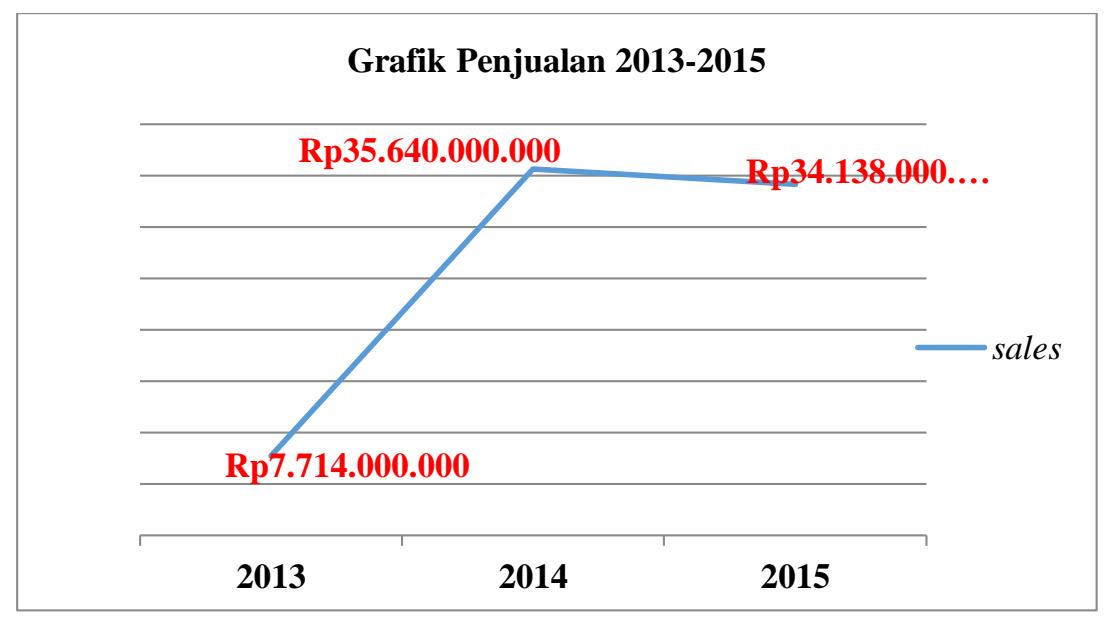

Sumber: Laporan Penjualan PT. Mahatherapoeitika (2016)

\section{Gambar 1 GRAFIK PENJUALAN RED KANK TAHUN 2013-2015}

Red Kank diinvensi tahun 2000 dengan tujuan untuk mengisi pangsa pasar bagi obat tradisional yang belum dilirik oleh perusahaan lain. Untuk itu, prototype obat herbal yang mula-mula diproduksi adalah obat herbal antikanker yang belum pernah diproduksi oleh industri obat di Indonesia. Red Kank adalah perintis obat herbal anti kanker di Indonesia. Akibat suksesnya memasarkan obat herbal anti kanker maka terobosan itu kemudian ditiru oleh perusahaan-perusahaan obat herbal lainnya, sehingga kini muncul beberapa industri obat herbal yang juga memproduksi obat herbal antikanker (Redkank, 2015).

Kini Red Kank melakukan diversifikasi produk dengan memerluas jenis produknya, yaitu di bidang kecantikan dan produk kesehatan lainnya (Tjetje, 2016; Redkank.com, 2015). Taleghani et al. (2011) dalam penelitian terhadap 258 responden di Tehran Iran yang bertujuan untuk menganalisis hubungan pelanggan dan merek dari sudut pandang pengalaman, menggambarkan niat pelanggan untuk membeli kembali sebagai pengaruh dari brand relationship quality (kepercayaan, kepuasan dan komitmen), service quality dan brand experiences. Berdasarkan latar belakang di atas, tujuan penelitian ini mengkaji tentang kualitas antara merek dan pelanggan dalam memanfaatkan relasinya untuk membangun dan mengembangkan loyalitas pelanggan melalui penggunaan wadah berbagi pengetahuan yang tepat. Hal tersebut dapat mengungkap hal-hal yang membuat pelanggan melakukan pembelian berulang, promosi lisan dan tindakan keluhan konstruktif.

\section{KAJIAN PUSTAKA DAN PENGEMBANGAN HIPOTESIS}

\section{Kualitas Merek}

Kualitas merek berkembang sebagai hubungan timbal balik antara merek dan konsumen. Hubungan antara merek dan konsumen terdiri dari dua dimensi, yaitu hubungan emosional dan komunikasi (Aji, 2021). Konsumen yang membentuk hubungan mendalam dengan merek cenderung untuk terlibat secara aktif dalam proses komunikasi dua arah, yaitu dalam memberikan dan menerima informasi yang diterjemahkan ke dalam penilaian positif dari kualitas, kepuasan, dan loyalitas (Kusuma et al., 2020). Clara (2019) menjelaskan kualitas merek akan berkembang melalui merek yang berarti (meaningful brand) dan tindakan konsumen (consumer actions), sehingga pada akhirnya dapat memerkuat atau memerlemah kualitas hubungan. 


\section{Wadah Berbagi Pengetahuan}

Wadah berbagi pengetahuan merupakan platform yang memfasilitasi proses koneksitas, proses membangun kepercayaan, dan proses pengambilan keputusan antar komunitas merek dengan para stakeholdernya (Panjaitan et al., 2017). Di samping itu, wadah berbagi pengetahuan sebagai sarana percepatan konektivitas. Dengan pemanfaatan wadah berbagi pengetahuan yang tepat dapat berpengaruh secara langsung terhadap sikap dan perilaku konsumen dalam pengambilan keputusan. Sumarlin et al. (2013) menemukan komitmen komunitas merek dipengaruhi langsung oleh wadah berbagi pengetahuan dengan menggunakan empat ruang yang ada di dalamnya. Empat ruang tersebut antara lain, 1) ruang material 2) ruang informasi 3) ruang alam pikir 4) ruang sosial.

\section{Perilaku Loyalitas}

Loyalitas dapat didasarkan pada perilaku pembelian aktual produk yang dikaitkan dengan proporsi pembelian. Memiliki konsumen dengan loyalitas yang tinggi memberi keuntungan bagi perusahaan karena dapat mengurangi biaya pemasaran perusahaan (Pramudyo, 2016). Promosi dan pengalaman konsumen terhadap merek juga turut memengaruhi hubungan antara konsumen dan merek, jika konsumen tidak puas maka tidak akan memiliki loyalitas terhadap merek yang berdampak pada peralihan terhadap merek lain (Ashfaq \& Lodhi, 2015). Humarah (2013) menyatakan bahwa konsumen yang puas menjadi rentan untuk melakukan pembelian berulang dan menolak pengaruh merek pesaing. Menurut Yuliawan \& Cuaca (2016), Loyalitas Konsumen akan melahirkan perilaku dan tindakan konsumen seperti, 1) Konsumen akan melakukan aktivitas transaksi secara teratur dan komitmen pada produk untuk tidak berpindah pada produk pesaing. 2) Perilaku konsumen yang bersifat memberikan rekomendasi mengajak orang lain untuk melakukan pembelian atau menggunakan produk tersebut. 3) Perilaku konsumen untuk membicarakan hal-hal yang positif terhadap produk ke orang lain. Pelanggan menunjukkan perilaku loyalitas kepada organisasi perusahaan diuntungkan dari hasil keuangan (Soehardi, 2021). Perilaku loyalitas menurut Sari et al. (2021), lebih mengacu pada wujud perilaku dari unit-unit pengambilan keputusan untuk melakukan pembelian secara terus-menerus terhadap barang atau jasa dari suatu perusahaan yang dipilih.

\section{Hubungan Antara Variabel}

Ismail et al. (2012) dalam penelitiannya mengenai pengaruh brand experience, brand trust, dan brand satisfaction terhadap brand loyalty di Vaxjo, Sweden menemukan bahwa variabel pengalaman, kepuasan dan kepercayaan merek semua memiliki hubungan yang positif dengan loyalitas merek. Hasil yang diperoleh dari pengujian hipotesis menunjukkan korelasi positif. Ini berarti bahwa semua hipotesis, pengalaman merek, kepuasan merek dan kepercayaan merek serta loyalitas merek diterima dalam penelitian ini. Untuk kepuasan merek dan loyalitas merek memiliki nilai korelasi yang lebih tinggi, yang menunjukkan bahwa elemen penting bagi loyalitas merek adalah kepuasan pelanggan. Kepercayaan merek dan loyalitas merek juga memiliki korelasi positif, yang berarti kepercayaan berpengaruh kuat terhadap suatu merek.

H1 : Terdapat hubungan positif antara kualitas merek dan perilaku loyalitas.

Hudson et al. (2016) menemukan bahwa penggunaan wadah media sosial memiliki pengaruh positif terhadap Kualitas Merek. Pelanggan yang memiliki ikatan dengan merek favoritnya dan menggunakan media sosial memiliki ikatan yang lebih kuat dengan merek dibandingkan dengan pelanggan yang tidak berinteraksi dengan merek favorit menggunakan media sosial.

De Wulf et al. (2001) menemukan bahwa semakin tinggi investasi terhadap hubungan pelanggan maka semakin tinggi komitmen untuk menjaga hubungan tersebut. Oleh karena itu, semakin banyak waktu yang dihabiskan untuk berinteraksi di media sosial maka kualitas hubungan merek dan pelanggan akan semakin kuat. Selama berinteraksi, pelanggan mendapatkan keuntungan berupa meningkatnya pengetahuan mereka mengenai produk, mengurangi risiko dari mengkonsumsi produk dan meningkatkan rasa percaya mereka terhadap merek. 
Serick et al. Pemanfaatan Wadah Berbagi Pengetahuan dan Kualitas Merek terhadap Perilaku Loyalitas Konsumen

Internet merupakan akses komunikasi yang memberikan kesempatan untuk berbagi informasi dan pengetahuan. Pelanggan suatu merek menggunakan internet sebagai komunitas virtual yang memengaruhi hubungan pelanggan terhadap merek. Interaksi sosial, reputasi wadah berbagi pengetahuan dan kepercayaan berdampak positif terhadap kualitas hubungan (Chang \& Chuang, 2011).

H2 : Terdapat hubungan positif antara kualitas merek dan wadah berbagi pengetahuan.

Sumarlin et al., (2013) menunjukkan bahwa wadah berbagi pengetahuan juga memiliki pengaruh terhadap komitmen dari komunitas merek. Komitmen yang terbentuk akan memengaruhi perilaku loyalitas konsumen dan niat beli konsumen. Komitmen komunitas merek dipengaruhi langsung oleh wadah berbagi pengetahuan dengan menggunakan empat ruang yang ada di dalamnya. T'Klooster \& Go (2004) menyarankan bahwa suatu komunitas merek akan lebih efektif dalam meningkatkan loyalitas pelanggannya bila mampu mengoptimalisasi ruang-ruang yang ada pada wadah berbagi pengetahuan. Wadah yang kedua ini memiliki empat ruang tempat berbagi pengetahuan yaitu ruang material (material space), ruang informasi (information space), ruang alam pikir (mind space) dan ruang sosial (social space). Pemanfaatan ruang-ruang tersebut akan menjadi daya tarik sendiri bagi konsumen karena fungsinya memermudah interaksi antar mereka dalam memeroleh informasi dan menggali pengetahuan.

H3 : Terdapat hubungan positif antara wadah berbagi pengetahuan dan perilaku loyalitas.

\section{METODE PENELITIAN}

Populasi penelitian ini adalah seluruh pelanggan dan pengguna akhir (end user) Red Kank yang berada di kawasan Jakarta, Bekasi, Surabaya, dan Balikpapan. Keterwakilan populasi oleh sampel dalam penelitian merupakan syarat penting untuk melakukan generalisasi. Teknik pengambilan sampel yang digunakan dalam penelitian ini yaitu dengan metode purposive sampling. Data diperoleh melalui penyebaran kuesioner. Variabel penelitian terdiri dari variabel eksogen yaitu kualitas merek dan variabel endogen yaitu wadah berbagi pengetahuan, dan perilaku loyalitas konsumen. Kualitas merek terdiri dari brand experience, brand satisfaction, dan brand trust (Kusuma et al., 2020). Wadah berbagi pengetahuan terdiri dari ruang material, ruang informasi, ruang alam pikir, dan ruang sosial (Sumarlin et al., 2013). Perilaku loyalitas konsumen terdiri dari pembelian berulang, word of mouth, dan keluhan konstruktif. Instrumen penelitian diukur menggunakan skala Likert. Metode analisis data menggunakan Structural Equation Modeling (SEM) dengan program Linear Structural Relationship (LISREL) 8.7.

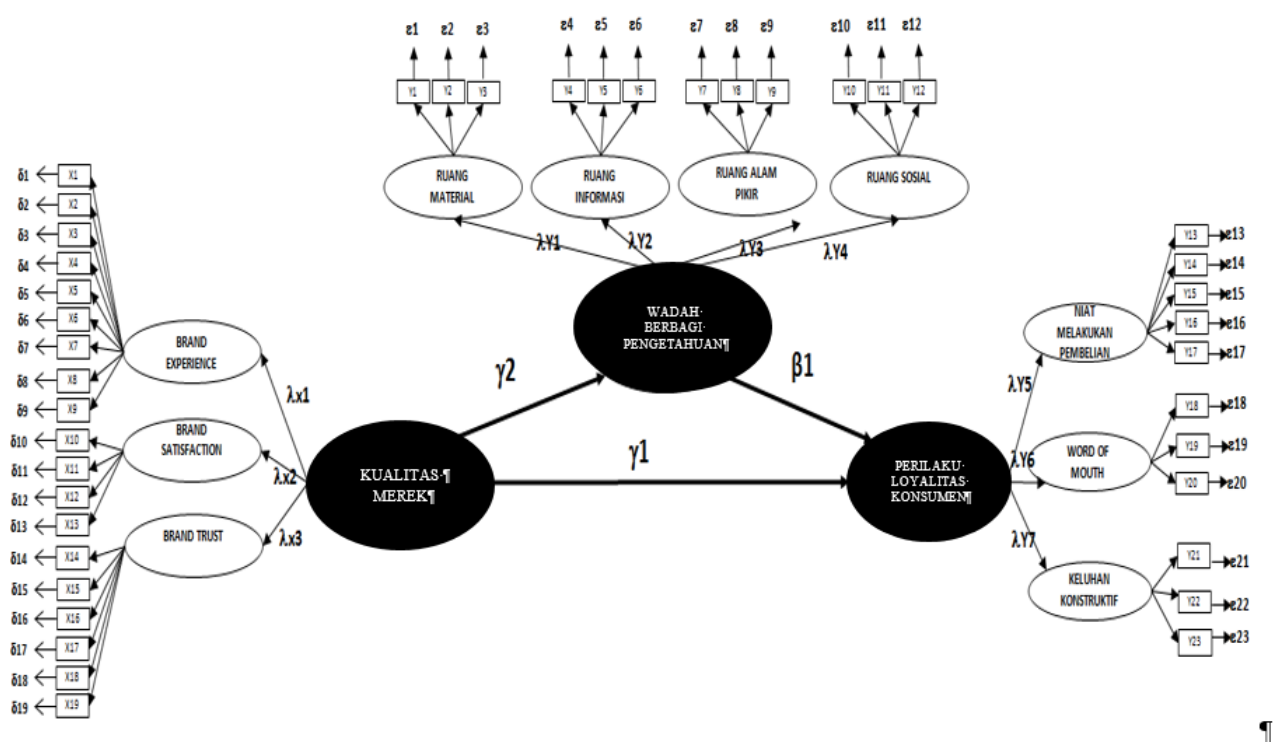

Gambar 2 MODEL PENELITIAN 


\section{HASIL DAN PEMBAHASAN}

Hasil pengujian hipotesis ditunjukkan pada gambar 3.

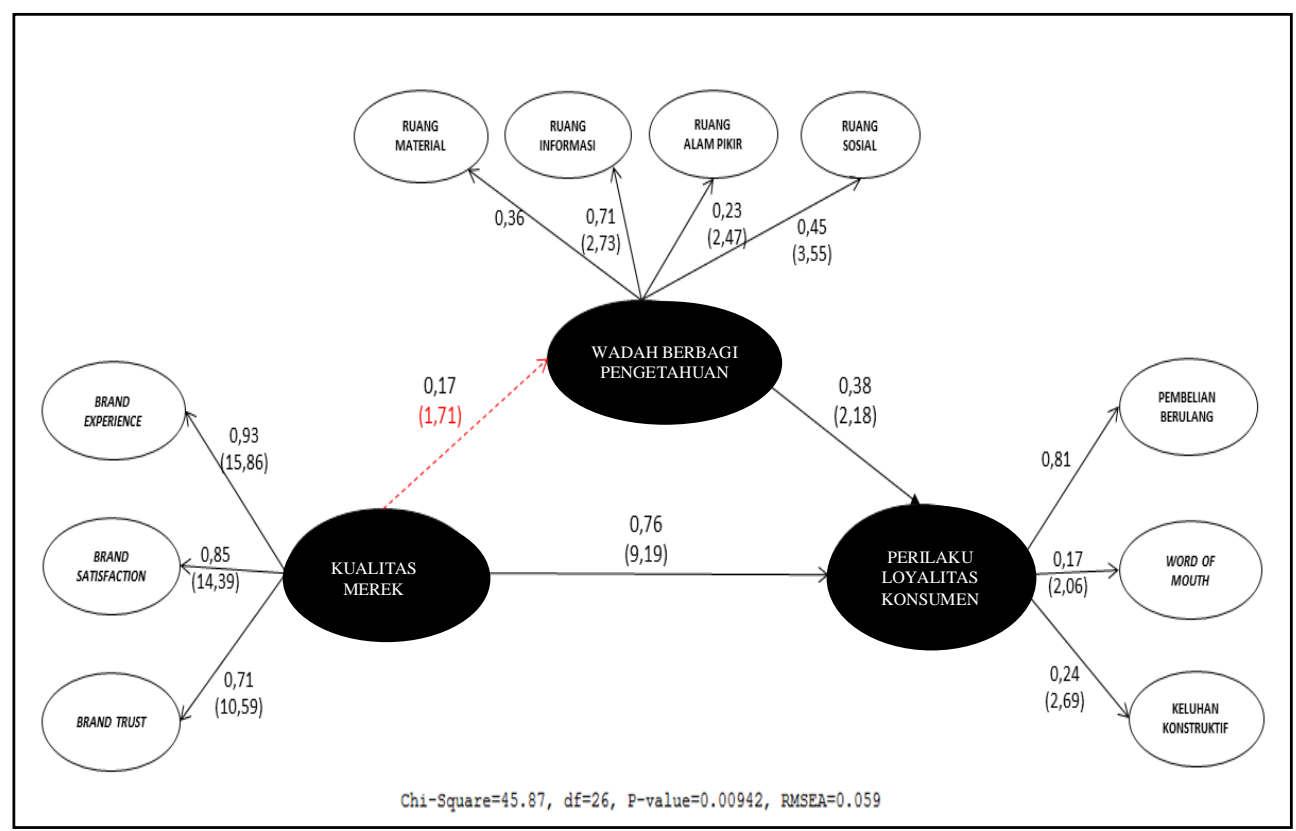

\section{Sumber : Diolah Penulis (2021) \\ Gambar 3 STANDARDIZED LOADING FACTOR DAN (T-VALUE) FULL MODEL}

Kualitas merek terdiri dari brand experience, brand satisfaction dan brand trust. Nilai loading factor ketiga dimensi yang membentuk kualitas merek adalah 0,93 untuk brand experience; 0,85 untuk brand satisfaction dan 0,71 untuk brand trust. Dari nilai loading factor tersebut brand experience memiliki nilai loading factor yang terbesar. Artinya, brand experience adalah dimensi yang paling dominan dalam membentuk kualitas merek. Nilai t-value untuk ketiga dimensi yang membentuk kualitas merek adalah valid karena memiliki nilai di atas 1,96. Construct reliability untuk kualitas merek adalah 0,87. Nilai ini di atas nilai yang disyaratkan, yaitu 0,70. Artinya, ketepatan dalam mengambil data adalah baik. Nilai variance extraction untuk kualitas merek adalah 0,70 yang berarti di atas nilai yang ditetapkan, yaitu 0,50. Hal ini berarti kemampuan dalam menjelaskan hubungan antar variabel sudah sesuai standar yang diharapkan.

Wadah berbagi pengetahuan terdiri dari ruang material, ruang informasi, ruang alam pikir, dan ruang sosial. Nilai loading factor keempat dimensi yang membentuk wadah berbagi pengetahuan adalah 0,36 ; 0,$71 ; 0,23$; dan 0,45 . Ruang informasi memiliki nilai loading factor yang paling besar. Hal ini berarti ruang informasi adalah yang paling dominan dalam membentuk variabel wadah berbagi pengetahuan. Nilai $t$-value untuk keempat dimensi yang membentuk wadah berbagi pengetahuan adalah valid karena memiliki nilai di atas 1,96. Construct reliability wadah berbagi pengetahuan adalah 0,50. Nilai ini tidak sesuai dengan standar yang ditetapkan, yaitu $\geq 0,70$. Jadi ketepatan dalam mengambil data adalah kurang baik. Sedangkan untuk nilai variance extraction adalah 0,22 . Nilai ini tidak sesuai dengan dengan standar yang ditetapkan, yaitu $\geq 0,50$. Artinya hubungan antar variabel belum sesuai dengan standar yang ditetapkan.

Perilaku loyalitas konsumen terdiri dari pembelian berulang, word of mouth dan keluhan konstruktif. Nilai loading factor kelima dimensi perilaku loyalitas konsumen adalah 0,$81 ; 0,17 ; 0,38$; dan 0,24 . Nilai $t$-value untuk ketiga dimensi yang membentuk perilaku loyalitas konsumen seluruhnya valid karena memiliki nilai di atas 1,96. Construct reliability perilaku loyalitas konsumen adalah 0,40. Nilai ini masih di bawah nilai yang disyaratkan, yaitu 0,70 . Artinya, ketepatan dalam mengambil data kurang 
Serick et al. Pemanfaatan Wadah Berbagi Pengetahuan dan Kualitas Merek terhadap Perilaku Loyalitas Konsumen

tepat. Nilai variance extraction untuk kepuasan kerja adalah 0,25 yang berarti di bawah nilai yang ditetapkan, yaitu 0,5. Hal ini berarti kemampuan dalam menjelaskan hubungan antar variabel belum sesuai standar yang diharapkan.

Hasil penelitian tersaji pada tabel 1 .

Tabel 1.

EVALUASI KOEFISIEN MODEL STRUKTURAL

\begin{tabular}{rllll}
\hline \multicolumn{1}{c}{ HIPOTESIS } & $\begin{array}{l}\text { Koefisien } \\
\text { lintasan }\end{array}$ & t-hitung & Keterangan \\
\hline H1 & $\begin{array}{l}\text { Terdapat hubungan positif antara kualitas merek } \\
\text { dan perilaku loyalitas konsumen }\end{array}$ & 0,76 & 9,19 & Signifikan dan Positif \\
H2 & $\begin{array}{l}\text { Terdapat hubungan positif antara kualitas merek } \\
\text { dan wadah berbagi pengetahuan }\end{array}$ & 0,17 & 1,71 & Tidak Signifikan \\
H3 & $\begin{array}{l}\text { Terdapat hubungan positif antara wadah berbagi } \\
\text { pengetahuan dan perilaku } \\
\text { loyalitas konsumen }\end{array}$ & 0,38 & 2,18 & Signifikan dan Positif \\
\hline
\end{tabular}

Sumber : diolah penulis (2021)

Berdasarkan tabel 1, pengaruh kualitas merek terhadap perilaku loyalitas konsumen. Karena nilai thitung lebih besar dari t-tabel dengan alpha 5\% yaitu 1,96 maka artinya kualitas merek terhadap perilaku loyalitas konsumen signifikan dan positif. Nilai koefisien path yang positif mengindikasikan kualitas hubungan antara merek dan pelanggan akan langsung berpengaruh positif terhadap perilaku loyalitas konsumen. Dengan demikian Hipotesis pertama diterima.

Pengaruh kualitas merek terhadap wadah berbagi pengetahuan memiliki koefisien path sebesar 0,17 dengan $t$ hitung 1,71. Karena nilai $t$ hitung lebih kecil dari $t$ tabel dengan alpha 5\% yaitu 1,96 maka artinya pengaruh kualitas merek terhadap wadah berbagi pengetahuan tidak signifikan. Dengan demikian hipotesis kedua ditolak.

Pengaruh wadah berbagi pengetahuan terhadap perilaku loyalitas konsumen memiliki koefisien path sebesar 0,38 dengan $t$ hitung 2,18. Karena nilai thitung lebih besar dari $t$ tabel dengan alpha $5 \%$ yaitu 1,96 maka a pengaruh wadah berbagi pengetahuan terhadap perilaku loyalitas konsumen adalah signifikan dan positif. Nilai koefisien path yang positif mengindikasikan penggunaan wadah berbagi pengetahuan yang tepat akan langsung berpengaruh positif terhadap perilaku loyalitas konsumen. Dengan demikian hipotesis ketiga diterima.

\section{Hubungan Brand Relationship Quality dan Perilaku Loyalitas Konsumen}

Berdasarkan hasil yang dikembangkan dalam penelitian ini maka dapat memerkuat konsep-konsep teoritis yang berkaitan dengan kualitas merek dan perilaku loyalitas konsumen. Hipotesa pertama yang telah dibuktikan, memerkuat teori yang dikemukakan oleh Taleghani et al. (2011) dan Ismail et al. (2012) bahwa kualitas merek berpengaruh positif terhadap loyalitas konsumen.

PT. Maha Thera Poeitika (Red kank) adalah badan usaha yang bergerak dalam berbagai bidang, antara lain bidang kesehatan. Perusahaan ini didirikan pada tahun 1990 oleh sejumlah orang yang diprakarsai oleh Aggi Tjetje (Pemilik gelar akademi terbanyak). Sebelum dikomersialkan, produk racikan Aggi Tjetje diperuntukkan bagi pasien secara cuma-cuma melalui suatu yayasan. Akan tetapi, akibat mahalnya bahan baku dan meningkat pesatnya permintaan obat dari pasien, membuat Red Kank terpaksa harus dikomersialkan demi keberlanjutan ketersediaan obat itu bagi masyarakat. Untuk itu, didirikanlah suatu koperasi dengan nama Koperasi Jaya Raya lalu menjadi PT. Maha Thera Poeitika (Red kank) agar tidak semata-mata komersial, namun ada nuansa sosial di samping komersial. Perusahaan ini kemudian berkiprah melalui pasang surut perjuangannya agar dapat tetap dapat memertahankan eksistensinya. 
Kini produknya di bidang kesehatan telah beragam, berupa obat minum dalam bentuk racikan, serbuk seduh, kapsul, pil, sediaan lain seperti cream, lotion, sabun, shampoo dan lain sebagainya yang semuanya berupa obat dalam dan luar. Kualitas merek antara Red Kank dan pelanggan diawali dari pengetahuannya atas manfaat produk, yaitu Red Kank sebagai "Redam Kanker". Hubungan merek dan pelanggan yang terjalin menciptakan loyalitas konsumen. Hubungan yang tercipta dari pengalaman baik pelanggan atas manfaat utama produk, yaitu sebagai peredam kanker menyebabkan pelanggan melakukan pembelian berulang.

Selain dikenal karena manfaatnya sebagai "Redam Kanker", merek Red Kank juga dikenal karena foundernya, yaitu Dr. Aggy TjeTje. Kepercayaan pelanggan yang timbul dari pengalamannya mengkonsumsi produk Dr. Aggy TjeTje menyebabkan loyalitasnya terhadap merek Red Kank. Di pasaran, terkadang ditemukan pelanggan menyebut produk Red Kank bukan dengan mereknya namun dengan sebutan "Obat Aggy Tjetje". Hal ini menjelaskan bahwa, merek Red Kank dikenal masyarakat hingga menyebabkan perilaku loyalitas pelanggannya dikarenakan manfaat produk dan founder produk tersebut.

\section{Hubungan Kualitas Merek dan Wadah Berbagi Pengetahuan}

Hasil pengujian menunjukkan bahwa tidak terdapat pengaruh kualitas merek terhadap wadah berbagi pengetahuan. HAsil ini tidak sejalan dengan DeWulf et al. (2001), dan (Chang \& Chuang, 2011). Pengetahuan terhadap merek Red kank yang selama ini dibagikan kepada konsumen hanya sebatas manfaat produk. Merek Red Kank dikenal masyarakat sebagai merek sebuah produk yaitu "redam kanker", bukan Red Kank sebagai sebuah merek korporasi (corporate brand). Jadi, pengetahuan mengenai merek yang ingin disampaikan oleh perusahaan melalui pemanfaatan wadah berbagi pengetahuan kurang tepat sasaran, karena informasi sampai ke pelanggan hanya mengenai manfaat produk, bukan Red Kank secara keseluruhan sebagai corporate brand dengan segala produknya selain redam kanker.

PT. Maha Thera Poeitika (Red Kank) juga menyediakan Klinik dan e-Klinik secara gratis untuk pelanggan Red Kank. Untuk berkonsultasi juga sangat mudah. Pasien dapat menghubungi pihak Red Kank untuk berkonsultasi secara gratis melalui e-Clinic dan telepon. Keberadaan Red Kank di masyarakat didukung melalui kampus kesehatan dengan nama Fakultas Usaha (Kesehatan) IABN, eClinic panti pengobatan tradisional Tian Da Ren Tang dengan sentuhan teknologi yang modern. Mayoritas Produk Red Kank diperuntukkan bagi pasien yang menderita penyakit kronis di mana penyakit tersebut sudah tidak mampu disembuhkan secara medis, misalnya penyakit kanker stadium lanjut, bagi lansia yang ingin memperoleh kualitas hidup tanpa pantangan, baik makanan, maupungaya hidup, serta bagi pasien yang ingin menjaga stamina tubuhnya.

Promosi produk Red Kank sendiri dilakukan melalui mulut ke mulut (word of mouth) berdasarkan testimoni dari pasien sendiri yang merasakan manfaat dari produk Red Kank. Selama 14 tahun belakangkan ini, Red Kank tidak dijual secara bebas mengingat sulitnya teknis pembuatannya sehingga tidak akan mampu memenuhi permintaan pasar apabila dipasarkan secara besar-besaran. Oleh karena itu, pemasarannya hanya melalui distribusi khusus yang dipercaya Red Kank, seperti agen, distributor, maupun penjualan secara langsung. Setelah menemukan cara mengolah obat tradisional secara modern tanpa mengurangi khasiatnya, Produk Red Kank kini sudah dapat diproduksi secara massal dari tahun 2013 sampai saat, dengan biaya yang lebih rendah.

\section{Hubungan Wadah Berbagi Pengetahuan dan Perilaku Loyalitas Konsumen}

Berdasarkan hasil yang dikembangkan dalam penelitian ini maka dapat memerkuat konsep-konsep teoritis yang berkaitan dengan wadah berbagi pengetahuan dan perilaku loyalitas konsumen. Hipotesa ketiga yang telah dibuktikan,memerkuat teori yang dikemukakan oleh Sumarlin et al. (2013) dan T'Klooster et al. (2004) yang menyatakan bahwa wadah berbagi pengetahuan memiliki pengaruh positif terhadap komitmen dan loyalitas. 
Pemanfaatan wadah berbagi pengetahuan yang tepat, yaitu ruang informasi untuk berbagi informasi mengenai manfaat produk akan meningkatkan intensitas pembelian yang dilakukan oleh pelanggan. Ruang informasi yang digunakan oleh Red Kank untuk berbagi informasi mengenai mereknya kepada pelanggan adalah televisi dan media cetak, seperti koran, majalah, brosur atau pamflet. Melalui informasi yang dibagikan, konsumen mengetahui mengenai manfaat produk dan merasakan sendiri manfaatnya. Setelah itu mereka akan terus melakukan pembelian atas produk Red Kank dan merekomendasikannya kepada orang lain untuk mengkonsumsi produk Red kank.

Sejak tahun 2014 hingga saat ini, mulai membenahi merek dengan desain logo yang lebih modern, pembuatan website secara professional dan mulai beriklan di media cetak seperti koran, majalah, dan menjadi sporsor berbagai macam event dan melakukan pameran, serta iklan di TV, akan tetapi dengan mengeluarin anggaran yang cukup besar untuk kegiatan promosi tersebut belum cukup juga untuk meningkatkan volume penjualan, ini mungkin karena perusahan belum bisa menentukan segmen dan metode pemasaran yang efektif dan efisien.

\section{KESIMPULAN}

Penelitian ini memberikan kontribusi secara khusus pada penelitian-penelitian tentang perilaku loyalitas konsumen yang sebelumnya telah diteliti oleh banyak ilmuwan dengan faktor-faktor atau variabel yang bervariasi sebagai sebuah rangkaian upaya meningkatkan loyalitas pelanggan. Hubungan positif antara kualitas merek terhadap perilaku loyalitas konsumen terbukti. Adanya pengaruh positif kualitas merek terhadap perilaku loyalitas konsumen menandakan adanya hubungan yang mengikat antara merek dan pelanggan terhadap perilaku loyalitasnya. Hubungan tersebut didasarkan oleh tiga basis, yaitu brand experience, brand satisfaction, dan brands trust.

Hubungan antara kualitas merek dan wadah berbagi pengetahuan adalah tidak signifikan. Hal ini berarti data yang dikumpulkan tidak berhasil membuktikan keterkaitan antara kualitas merek dan wadah berbagi pengetahuan. Hubungan positif wadah berbagi pengetahuan dan perilaku loyalitas konsumen terbukti. Adanya pengaruh positif wadah berbagi pengetahuan terhadap perilaku loyalitas konsumen menandakan bahwa wadah yang digunakan oleh konsumen untuk berbagi pengetahuan akan memengaruhi perilaku loyalitasnya. Perilaku loyalitas tersebut terdiri dari pembelian berulang, word of mouth, dan keluhan konstruktif.

Merek Red Kank sangat identik dengan "Redam Kanker". Sejauh ini yang dikomunikasikan oleh merek Red Kank melalui ruang informasi untuk meningkatkan loyalitas pelanggan hanyalah manfaat produknya. Hubungan merek dan pelanggan terkait dengan manfaat produk, jadi sulit untuk Red Kank menjadi sebuah corporate brand dengan segala diversifikasi produknya.

Studi ini memiliki keterbatasan. Ruang lingkup subjek yang diteliti dalam penelitian ini adalah pelanggan akhir merek Red Kank di daerah Jakarta, Bekasi, Surabaya, dan Balikpapan. Konsekuensinya, hasil studi ini tidak dapat digeneralisir pada daerah lain dan pada industri lain baik yang sejenis maupun yang berbeda. Karenanya, untuk memerkuat generalisasi hasil studi, penelitian selanjutnya hendaknya mengkaji pada area yang berbeda, baik dalam lingkup produk yang berbeda maupun industri yang berbeda. Selain itu, dapat juga ditambahkan variabel lain seperti brand aura untuk mengetahui aura yang diterima oleh pelanggan merupakan aura produk atau aura founder.

\section{DAFTAR PUSTAKA}

Aji, B. S. (2021). Pengaruh Pembelajaran Hubungan Pelanggan terhadap Nilai Pelanggan melalui Kualitas Layanan, Citra Perusahaan dan Kualitas Produk yang Dampaknya terhadap Keterlibatan Pelanggan Pada PT Bank Pembangunan Daerah Jawa Timur Tbk Wilayah Surabaya. Doctoral dissertation, Universitas 17 Agustus 1945 Surabaya.

Ashfaq, H., \& Samreen, L. (2015). Factors Leading to Brand Switching in Cellular Phones: A Case of Pakistan. Journal of Marketing and Consumer Research, 17(10), 32-40. 
Arisena, G. M. K. (2016). Konsep Kewirausahaan pada Petani melalui Pendekatan Structural Equation Model (SEM). Jurnal Agribisnis dan Agrowisata, 5 p 57-68

Chang HH, Chuang SS. (2011). Social Capital and Individual Motivations on Knowledge Sharing: Participant Involvement as a Moderator. Information \& Management. 48. 9-18.

Clara, C. (2019). Customer Brand Relationship: Peran Brand Love terhadap Brand Commitment dan Positive Word of Mouth. Buletin Ekonomi, 17(1), 29-46.

De Wulf K, Oderkerken SG, Iacobucci D. (2001). Investment in Consumer Relationships: A Crosscountry and Cross-industry Exploration. Journal of Marketing, 65, 33-50.

Hudson, S., Huang, L., Roth, M. S., \& Madden, T. J. (2016). The Influence of Social Media Interactions on Consumer-Brand Relationships: A Three-Country Study of Brand Perceptions and Marketing Behaviors. International Journal of Research in Marketing, 33(1), 27-41.

Humarah, F. A. (2013). Kepuasan dan Loyalitas Konsumen pada Online Market di Indonesia. Jurnal Manajemen dan Pemasaran Jasa, 6, 219-259.

Ismail R, Boye CL, Muth A. (2012). Customer Brand Relationship An Empirical Study of Customers' Perception of Brand Experience, Brand Satisfaction, Brand Trust and How They Affect Brand Loyalty. Thesis Linnaeus University, p 53

Kaur, J., \& Bhardwaj, N. (2021). Their Control will Make or Break the Sustainable Clothing Deal-A Study of the Moderating Impact of Actual Behavioural Control on the Purchase IntentionBehaviour Gap for Sustainable Clothing in India. Australiasian Accounting, Business and Finance Journal, 15(5), 59.

Kusuma, A. H. P., Sudirman, A., Purnomo, A., Aisyah, S., Sahir, S. H., Rumondang, A., ... \& Simarmata, J. (2020). Brand Management: Esensi, Posisi dan Strategi. Medan: Yayasan Kita Menulis.

Merdiani, w. (2021). Pengaruh Pemasaran Hubungan Pelanggan dan Citra Merek Terhadap Nilai Pelanggan dan Keunggulan Bersaing serta Implikasinya pada Loyalitas Pelanggan (Suatu Survei Pada Hotel Non Bintang, Bintang Satu dan Dua di Bandung Raya). Doctoral dissertation, Perpustakaan Pascasarjana Universitas Pasundan.

Panjaitan, L., Purwoko, B., \& Sumarlin, A. W. (2017). Analisis Strategi Fungsional dalam Pengelolaan Merek Properti terhadap Loyalitas Pelanggan. Ekobisman-Jurnal Ekonomi Bisnis dan Manajemen, 2(1), 58-76.

Pramestika, S., Lukito, W., \& Adhika, F. A. (2020). Strategi Desain dan Implementasi pada Media Visual PT Etos Indonusa. eProceedings of Art \& Design, 7(2),1-20.

Pramudyo, A. (2016). Pengaruh Citra Merek Terhadap Loyalitas Melalui Kepuasan Sebagai Intervening (Studi pada Mahasiswa Perguruan Tinggi Swasta di Yogyakarta). Jurnal Bisnis, Manajemen, dan Akuntansi, 1(1), 1-16.

Redkank (2015). Redam Kanker, Dalam https://www.redkank.com/article/footer_content/1-generalfaqs, diakses pada 12 Desember 2021

Sari, D. P. H., Mitariani, N. W. E., \& Imbayani, I. G. A. (2021). Pengaruh Brand Trust, Service Quality dan Customer Satisfaction Pada Loyalitas (Studi Pada Pelanggan Gojek di Kota Denpasar). Jurnal Emas, 2(2), 43-50. 
Serick et al. Pemanfaatan Wadah Berbagi Pengetahuan dan Kualitas Merek terhadap Perilaku Loyalitas Konsumen

Soehardi, S. (2021). Model Peningkatan Volume Penjualan Melalui Kualitas Produk, Kualitas Pelayanan dan Loyalitas Kopi Golda. Jurnal Manajemen Strategi dan Aplikasi Bisnis, 4(2), 353 360.

Sumarlin AW, Soehadi AW, Suharjo B, Daryanto HK. (2013). Pengaruh Wadah Berbagi Pengetahuan terhadap Komitmen dari Komunitas Merek. Jurnal Manajemen Teknologi, 12(1).88-101.

Sridadi, A. R. (2013). Kajian Atas Konsep"" dari Keunggulan Kompetitif Berkelanjutan Nicole P. Hoffman dan Pengembangannya. Jurnal Ekonomi dan Bisnis Airlangga, 23(3).

T'Klooster EV, Go F, Baleen P. (2004). Exploring Destination Brand Community: A Business Model for Collaboration in The Extremely Fragmented Tourism Industry. Centre for Tourism Management. Netherlands: Rotterdam School of Management.

Taleghani M, Largani MS , Mousavian SJ. 2011. The Investigation and Analysis Impact of Brand Dimensions on Services Quality and Customers Satisfaction in New Enterprises of Iran. Contemporary Marketing Review Vol. 1(6) pp. 01 - 13, August, 2011.

Yuliawan, E., \& Cuaca, W. (2016). Mengukur Loyalitas Pelanggan pada Brastagi Supermarket (Jl Gatot Subroto Medan). Jurnal Wira Ekonomi Mikroskil: JWEM, 6(2), 177-192. 